\title{
BUDAYA POLITIK PEREMPUAN PESISIR: STUDI PERILAKU POLITIK PEREMPUAN DI KABUPATEN INDRAMAYU
}

\author{
Oleh: Iis Khaerunisah*, M. Japar, Suhadi*
}

\begin{abstract}
This study aims to explain the political culture of Indramayu women through political behaviour and political orientation. The method used is descriptive method with qualitative approach. Data collection was carried out through observation, literature studies, and in-depth interviews. The results of the study show that women's political participation in Indramayu is quite high, especially in the legislatives and excecutive institutions. However, women politicians have not succeeded in fighting for the maximum issue of womens. This happens because of their limited ability and knowledge of the problem that arise. Most female politicians do not have adequate education. They appear as politicians instaneously who rely on the influence of family or relatives who dominate the local bureaucracy.
\end{abstract}

Keywords: Women, political culture, political participation.

\section{A. PENDAHULUAN}

Keterwakilan perempuan di dalam ranah politik memiliki peran yang sangat penting dalam membangun sistem politik yang berkeadilan gender. Hal ini disebabkan karena apabila keterwakilan perempuan dalam ranah politik diabaikan maka mekanisme pembuatan kebijakan publik diserahkan sepenuhnya kepada lakilaki sebagai wakil perempuan akan menghasilkan kondisi bias gender. Ada beberapa alasan pentingya keterwakilan perempuan dalam bidang politik diantaranya yaitu pertama, perempuan memiliki pengalaman khusus yang dipahami dan dirasakan oleh perempuan. Seperti isu dikriminasi, marginalisasi, kesehatan reproduksi, kekerasan dalam rumah tangga, kekerasan seksual dan sebagainya.

Kedua, keterwakilan perempuan dalam bidang politik juga diharapkan mampu mencegah kondisi-kondisi yang tidak menguntungkan perempuan dalam mengatasi permasalahan strereotipe terhadap perempuan, diskrimininasi

\footnotetext{
* Guru PPKN pada Sekolah Menengah Atas di Jakarta dan alumni Prodi PPKN UNJ

- Dosen Prodi PPKN Fakultas Ilmu Sosial Universitas Negeri Jakarta

* Dosen Prodi PPKN Fakultas Ilmu Sosial Universitas Negeri Jakarta
} 
di bidang hukum, kehidupan sosial dan kerja, marginalisasi di dunia karier dan eksploitasi lain yang terjadi kepada perempuan.

Ketiga, keterwakilan perempuan dalam politik juga diharapkan mampu membawa nuansa baru dalam panggung politik. Panggung politik saat ini cenderung maskulin. Sehingga kehadiran perempuan diharapkan dapat mengutamakan kedamaian dalam perbedaan, membawa nilai-nilai kelembutan, mengatasi perkelahian dengan berembuk, mengubah kompetisi menjadi kerjasama.

Lebih dari semua yang telah dipaparkan di atas, keterwakilan perempuan dalam politik merupakan manifestasi dari pemenuhan hak kewarganegaraannya (Partini 2014: 29). Salah satu hak yang dianugerahkan oleh negara kepada seorang warga negara adalah hak untuk berpartisipasi dalam bidang politik yang mekanismenya telah diatur dalam perundang-undangan. Sebagai upaya untuk menghasilkan kebijakan yang holistik dan pro gender, maka pemerintah membuat peraturan perundang-undangan yang menjamin kesetaraan partisipasi perempuan dalam ranah politik yang dituangkan dalam Undang-Undang Dasar 1945, Undang-Undang No 39 tahun 1999 tentang Hak Asasi Manusia, dan Undang-Undang No 2 tahun 2011 tentang Partai Politik. Dari beberapa produk hukum diatas menyatakan bahwa perempuan memiliki hak dan kesempatan yang sama dengan laki-laki dalam berpartisipasi sebagai aktor politik yang berperan dalam menentukan kebijakan publik

Undang-Undang No 2 tahun 2011 Pasal 2 ayat (2) menyebutkan "pendirian dan pembentukan parpol menyertakan $30 \%$ keterwakilan perempuan. Ayat (5) kepengurusan parpol tingkat nasional disusun dengan menyertakan paling rendah $30 \%$ keterwakilan perempuan. Pasal 20 mengatur bahwa kepengurusan parpol tingkat provinsi dan kabupaten/kota disusun dengan memperhatikan keterwakilan perempuan paling rendah $30 \%$ yang diatur dalam anggaran dasar dan anggaran rumah tangga parpol masing-masing,

Meski telah diberikan kuota sebesar 30\% melalui Undang-Undang tentang Partai Politik. Hal ini ternyata 
belum signifikan mempengaruhi keterwakilan perempuan dalam ranah politik. Kesenjangan gender masih sangat mencolok terlihat dalam komposisi anggota legislatif di parlemen. Menurut data Internasional-Parlementery Union yang dikutip PBB pada tahun 2013, perempuan hanya menduduki $20.3 \%$ dari total parlemen dunia. Hal ini sudah lebih baik dari $15,4 \%$ ditahun 2004. Padahal jika kita merujuk pada Deklarasi Beijing, perempuan diberikan kuota sebesar 30\% (Ani Soetjipto 2013: 116). Hal serupa juga terjadi di Indonesia, menurut Center for Electoral Reform pada tahun 2009-2014 perempuan hanya menempati $18.04 \%$ kursi di parlemen (Harien Puspitawati 2012: 140).

Di Indonesia sendiri perilaku perempuan lebih banyak dipengaruhi oleh faktor-faktor sosial dan kultural. Politik diidentikan dengan dunia yang kotor, sarat konflik, penuh intrik, kompetitif dan keras. Kondisi sistem politik yang maskulin menuntut seorang aktor politik cerdas, tegas, tangguh, sigap, dan visioner dalam mengambil sebuah keputusan.

Kondisi partisipasi perempuan diberbagai daerah cenderung rendah, hal berlawanan justru terjadi di sebuah daerah di Pantai Utara Jawa tepatnya di Kabupaten Indramayu. Perempuan di Kabupaten Indramayu berbondong-bondong terjun ke arena politik. Hal ini dapat dilihat dari tingginya daftar calon legislatif yang ikut berpartisipasi dalam Pemilu. Saat ini 13 orang anggota DPRD Kabupaten Indramayu periode 20142019 adalah perempuan. Jumlah tersebut hanya $23 \%$ dan belum memenuhi kuota $30 \%$ yang disediakan namun angka partisipasi ini cukup tinggi. Hal serupa juga dapat dari ranah eksekutif dimana Indramayu dipimpin oleh seorang bupati perempuan bernama $\mathrm{Hj}$. Anna Sophana.

Substansi dari keterwakilan perempuan dalam ranah politik termanifestasi pada perilaku politiknya. Perilaku politik merupakan salah satu aspek pembentuk budaya politik. Karena budaya politik disusun oleh orientasi politik dan perilaku politik. Dengan melihat perilaku politisi dan orientasi politik perempuan di Indramayu kita akan mendapatkan gambaran tentang budaya politik lokal. Karena aktor merupakan agency budaya namun 
juga seorang kreator budaya itu sendiri. Berdasarkan pemaparan diatas peneliti tertarik untuk meneliti budaya politik perempuan pesisir. Berdasarkan pemaparan latar belakang diatas maka masalah pokok yang diajukan dalam penelitian ini yaitu, bagaimanakah orientasi politik perempuan Indramayu, serta bagaimanakah perilaku politik perempuan Indramayu?

\section{B. KAJIAN PUSTAKA}

\section{a. Budaya Politik}

Lucian Pye memahami budaya politik sebagai pendekatan kebudayaan yang mencari pemahaman yang eksplisit dan sistematis tentang orientasi politik dan perilaku politiknya. Sedangkan menurut Eckstein komponenkomponen budaya politik tersebut bisa diringkas sebagai kecenderungan tersendiri atau sebagai orientasi tindakan (Dian Rinantasari 2013: 18). Budaya politik lazimnya diartikan sebagai perangkat sikap, kepercayaan, dan perasaan warga negara terhadap sistem politik dan simbol-simbol seperti bendera, bahasa, dan lembaga-lembaga politik yang dimilikinya (Nazaruddin
Sjamsuddin 1993: 90). Jadi bagaimana bentuk sikap, kepercayaan, dan perasaan seseorang terhadap sistem politik ditentukan oleh bagaimana hubungan antara kebudayaan masyarakat dengan sistem politiknya.

Mohtar Mas'oed menjelaskan bahwa berdasarkan sikap, nilai-nilai, informasi, dan kecakapan politik yang dimiliki dapat menggolongkan orientasi-orientasi warga negara terhadap kehidupan politik dan pemerintahan negaranya. Atau dengan kata lain dapat menggolongkan kebudayaan politiknya (Mohtar Mas'oed 1995: 41). Almond dan Verba mendefinisikan budaya politik sebagai suatu sikap orientasi khas warga negara terhadap sistem politik dan aneka ragam bagiannya dan sikap terhadap peranan warga negara yang ada di dalam sistem itu. Rusadi Sumintra Putra mendefinisikan budaya politik sebagai pola tingkah laku individu dan orientasinya terhadap kehidupan politik yang dihayati oleh para anggota suatu sistem politik.

Sidney Verba mendefinisikan budaya politik sebagai suatu sistem 
kepercayaan empiris, simbol-simbol ekspresif dan nilai-nilai yang menegaskan suatu situasi di mana tindakan politik dilakukan (Mohtar Mas'oed 1995: 98). Budaya politik memungkinkan untuk menganalisa interaksi antara sistem politik dengan lingkungannya, yaitu para elite dan tingkah laku masyarakatnya. Hal ini disebabkan karena kebijaksanaan yang diberikan elite mempunyai pengaruh yang sangat kuat terhadap tingkah laku masyarakat (Albert Widjaja 1988: 39). Berdasarkan pemaparan diatas dapat disimpulkan bahwa budaya politik adalah sistem nilai dan keyakinan yang dimiliki oleh masyarakat yang diwujudkan dalam bentuk pola orientasi politik dan perilaku politik masyarakat terhadap sistem politiknya dalam sebuah wilayah.

\section{b. Perilaku Politik}

Perilaku politik (political behavior) adalah perilaku yang dilakukan oleh seseorang secara individual atau secara kelompok guna memenuhi hak dan kewajibannya sebagai insan politik. Seorang atau kelompok memiliki kewajiban yang telah diberikan oleh negara untuk melakuan hak dan kewajibannya berupa perilaku politik. Interaksi antara pemerintah dan masyarakat di antara lembaga-lembaga pemerintah dan di antara kelompok dan individu dalam masyarakat dalam rangka proses pembuatan, pelaksanaan dan penegakan keputusan politik, pada dasarnya merupakan perilaku politik (Surbakti 2010: 20).

\section{Sedangkan Sudijono} mengungkapkan bahwa perilaku politik adalah dapat berupa perilaku lembaga-lembaga politik dan dapat berupa perilaku individu. Perilaku politik yang disebut pertama adalah dijalankan oleh lembaga-lembaga politik sesuai dengan tugas dan wewenang yang ada padanya, sedangkan yang disebut terakhir perilaku politik adalah yang dijalankan oleh tiap-tiap individu sebagai peran serta didalam kehidupan politik (Sudijono Sastroatmodjo 1995: 67). Sementara itu, Robert K Carr merumuskan bahwa perilaku politik adalah suatu telaah mengenai tindakan manusia dalam situasi politik. Situasi politik sendiri sangat luas cakupannya antara lain respons emosional berupa dukungan atau tuntutan maupun skiap 
apatis terhadap pemerintah dan kebijakan publik dan lain-lain.

Aktivitas atau peilaku politik merupakan aktivitas manusia yang berhubungan dengan bagaimana distribusi kekuasaan dan kewenangan di dalam suatu negara dijalankan, juga aktivitas yang berupa aksi dan reaksi yang berhubungan dengan kebijakan publik sebagai produk dari proses politik dalam struktur politik Elly M. Setiadi dan Usman Kolip 2009: 131). Dari berbagai pendapat diatas dapat disimpulkan bahwa perilaku politik merupakan serangkaian perilaku kelompok maupun perilaku individu dalam rangka memenuhi hak dan kewajibannya sebagai makhluk politik. Perilaku politik juga merupakan representasi dari orientasi politik kelompok maupun individu terebut.

c. Faktor-faktor Mempengaruhi Politik

Dalam mengkaji perilaku politik aktor politik tentunya sangat penting mengkaji faktor-faktor yang mempengaruhi perilaku politik. Perilaku politik banyak dipengaruhi oleh berbagai dimensi latar belakang yang merupakan bahan dalam pertimbangan politiknya. Dalam kenyataannya tindakan politik tidak hanya ditentukan oleh tugas dan kewenangan yang melekat pada lembaga atau seseorang tapi juga dipengaruhi oleh kepribadian (keinginan dan dorongan, persepsi dan motifasi, sikap dan orientasi, harapan dan cita-cita, ketakutan dan pengalaman masa lalu) individu yang mengambil keputusan itu (Surbakti 2010: 168). Selain itu juga ada faktorfaktor yang mempengaruhi perilaku politik aktor politik, yaitu:

Pertama, lingkungan sosial politik tak langsung, seperti sistem politik, sistem ekonomi, sistem budaya dan media massa. Kedua, lingkungan sosial politik langsung yang mempengaruhi dan membentuk kepribadian aktor, seperti keluarga, agama, pendidikan, dan kelompok pergaulan. Seorang aktor akan mendapatkan sosialisasi berupa norma dan pengalaman dari lingkungan sosial politik langsungnya. Sedangkan lingkungan sosial politik langsung sendiri juga banyak dipengaruhi oleh lingkungan politik tak langsung. 
Ketiga, struktur kepribadian yang tercermin dalam sikap individu. Untuk memahami struktur kepribadian terdapat tiga basis fungsional sikap, yaitu kepentingan, penyesuaian diri, eksternalisasi, dan pertahanan diri. Keempat, faktor lingkungan sosial politik langsung berupa situasi, yaitu keadaan yang mempengaruhi aktor secara langsung ketika hendak melakukan suatu kegiatan, seperti cuaca, keadaan keluarga, keadaan ruang, kehadiran orang lain, suasana kelompok dan ancaman dengan segala bentuknya (Surbakti 2010: 170).

\section{d. Politisi Perempuan}

Politisi perempuan merujuk pada istilah yang digunakan untuk aktor politik yang berjenis kelamin perempuan. Jadi secara konsep pendekatan yang dibahas adalah pendekatan elite politik. Fifredo Pareto mengatakan bahwa yang disebut dengan kelompok elite adalah sekelompok kecil individu-individu yang memiliki kualitas-kualitas terbaik, yang dapat menjangkau pusat kekuasaan sosial politik. Elite merupakan orang-orang yang berhasil dan mampu menduduki jabatan tinggi dalam lapisan masyarakat (Elly M.

Setiadi dan Usman Kolip 2009: 40).

\section{METODE PENELITIAN}

Penelitian ini dilakukan dengan menggunakan pendekatan kualitatif dengan metode deskriptifDalam penelitian kualitatif teknik pengambilan data dilakukan dengan observasi, wawancara dan dengan dokumentasi. Pengambilan sampel dilakukan dengan snowball. Analisis data bersifat induktif dan hasil penelitian menekankan pada makna daripada generalisasi (Sugiyono 2008: 5).

\section{HASIL PENELITIAN DAN PEMBAHASAN \\ TEMUAN PENELITIAN}

Berdasarkan penelitian yang telah dilakukan didapatkan berbagai data-data penelitian sebagai berikut:

\section{a. Orientasi Politik Perempuan Indramayu}

Dalam tatanan pemerintahan di Indramayu orientasi politik berisi tentang kecenderungan seseorang dalam berpolitik. Hal ini berisi tentang keaktifan seseorang dalam bidang politik, partisipasi dalam 
PILKADA, pertimbangan dalam melakukan kegiatan politik, respon emosional terhadap pemerintah, dan kemampuan dalam memberikan penilaian terhadap jalannya pemerintahan.

Orientasi politik dibentuk oleh tiga dimensi yaitu dimensi kognitif, afektif dan evaluatif. Orientasi kognitif berisi tentang pengetahuan seseorang tentang sistem politiknya. Karena berisi tentang pengetahuan maka hal ini membuat orientasi kognitif menjadi landasan bagi perempuan Indramayu dalam melakukan orientasi afektif dan orientasi evaluatif. Salah satunya adalah hak dalam memberikan hak suara saat pemilu. Selain dapat mengetahui hak dan kewajibannya pada saat pemilu perempuan Indramayu juga mampu mengetahui isu-isu yang ada di Indramayu saat ini serta mampu memberikan tanggapan terhadap isu tersebut. Isu yang disampaikan oleh perempuan Indramayu umumnya beragam karena dipengaruhi oleh latar belakang dari perempuan Indramayu itu sendiri.

Selain isu politik yang ada di dunia pendidikan ada juga isu lain yang diketahui oleh perempuan
Indramayu. Seperti adanya upaya terstruktur yang dilakukan oleh beberapa pihak untuk membuat masyarakat Indramayu menjadi bungkam dengan cara memberikan uang pada saat ada isu yang dirasakan oleh masyarakat Indramayu sementara orang yang mengkitisi dianggap sebagai provokator. Seorang aktifis perempuan di Indramayu mengatakan bahwa:

Selain aspek pengetahuan aspek yang ada dalam orientasi politik adalah aspek afektif. Dalam aspek ini perempuan Indramayu mampu menyampaikan perasaannya terhadap pemerintah. Misalnya terkait banyaknya perempuan yang terjun ke ranah politik. Saat ini ada dua belas perempuan yang menjadi anggota DPRD serta terpilihnya kembali Anna Sophanah menjadi bupati untuk yang kedua kalinya. Perempuan Indramayu menganggap bahwa ini merupakan hal yang positif.

Perempuan Indramayu memiliki harapan yang terhadap perempuan yang saat ini ada di parlemen maupun di eksekutif. mereka berharap bahwa perempuan Indramayu yang saat ini memimpin indramayu memiliki kepedulian yang 
tinggi kepada rakyat sera mampu memperbaiki citra negatif terhadap perempuan Indramayu yang seakan begitu melekat seperti kegemaran kawin-cerai, pernikahan dibawah umur serta perempuan Indramayu yang terkenal sebagai pekerja seks komersial di berbagai daerah.

Selain diharapkan dapat memperbaiki citra negatif yang ada saat ini peremuan Indramayu yang terjun ke ranah politik juga diharapkan mampu untuk menjadi contoh atau role model bagi perempuan Indramayu yang lain.

Bukan hanya dinilai belum mampu memperbaiki citra negatif yang ada di Indramayu banyaknya perempuan Indramayu yang terjun ke ranah politik juga belum berdampak pada terlindunginya hak-hak perempuan di Indramayu. Seperti yang diketahui bahwa perempuan Indramayu banyak yang menjadi buruh migran ke Timur Tengah. Perempuan yang menjadi pahlawan devisa negara ini sangat riskan terhadap tindakan-tindakan kekerasan yang dilakukan oleh majikannya.

Berdasarkan hasil observasi yang dilakukan belum maksimalnya kinerja pemerintah Kabupaten
Indramayu juga dilihat dari pasifnya perempuan Indramayu saat mengikuti rapat paripurna. Tiga kali dilakukan observasi saat sidang paripurna tidak ada anggota DPRD perempuan yang aktif memberikan pendapat, bertanya atau memberikan sangahan terkait masalah yang sedang diperbincangkan saat rapat. Setiap kali ada agenda rapat paripurna yang dibuat oleh Badan Musyawarah selalu saja rapat dimulai selalu mundur satu jam dari waktu yang sudah ditetapkan.

Ketidakpahaman anggota DPRD terhadap peran dan fungsinya juga dapat dilihat dari hasil wawancara yang dilakukan. Salah seorang anggota DPRD perempuan di Indramayu tidak dapat membedakan antara program dari badan legislatif dengan program dari badan eksekutif. Tentu saja hal ini sangat mengherankan karena aktor politik seharusnya memiliki pengetahuan dan pemahaman yang tinggi terkait peran, fungsi dan programnya. Bagaimana mungkin seorang aktor dapat bekerja dengan maksimal jika aktor politik tersebut tidak bisa membedakan program legislatif dengan program legislatif. 
Kurang berkualitasnya sosok aktor politik perempuan yang saat ini memimpin Indramayu baik di bidang eksekutif maupun bidang legislatif juga dapat dilihat dari ketidakmampuan aktor politik perempuan ini dalam membangun opini publik. Keterampilan seorang aktor politik dalam membangun opini publik dinalai sangat penting. Karena dapat meningkatkan legitimasi saat seorang aktor mengambil kebijakan. Namun sayangnya tidak satupun dari perempuan yang saat ini memimpin Indramayu yang melakukan pembangunan opini publik dengan menulis opini di surat kabar ataupun buku.

Keterbatasan sumberdaya manusia yang terjadi politisi perempuan Indramayu saat ini bukan hanya terjadi pada satu dua orang politisi pada politisi perempuan Indramayu saja. Hanya sebagian kecil politisi perempuan Indramayu saja yang memiliki pendidikan sampai S1, kebanyakan dari mereka hanya menyelesaikan pendidikan formal sampai sekolah menengah atas. Setelah menjadi anggota parlemen baru ada sebagian kecil yang melanjutkan ke jenjang pendidikan yang lebih tinggi.

Berdasarkan pemaparan diatas dapat disimpulkan bahwa ada beberapa indikator kurang berkualiasnya politisi perempuan di Indramayu saat dapat dilihat dari belum maksimalnya kinerja politisi perempuan, ketidakmampuan dalam membuat kebijakan yang mampu menjadi solusi konkret dari permasalahan serta ketidakmampuan membangun opini publik. Belum maksimalnya kinerja serta kurang berkualitasnya politisi perempuan yang memimpin Indramayu saat ini adalah salah satu dampak dari keterbatasan sumber daya manusia yang dimiliki oleh politisi perempuan yang memimpin Indramayu tersebut.

\section{b. Perilaku Politik Perempuan Indramayu}

Perilaku politik dimaknai sebagai segala aktifitas yang dilakukan oleh oleh seseorang dalam rangka memenuhi hak dan kewajibannya sebagai aktor politik. Merujuk pada hal tersebut maka perilaku politik dapat diwujudkan dalam pemberian suara saat PILKADA, aktif dalam suatu partai 
politik, ormas atau LSM, memberikan kritik, saran atau dukungan kepada pemerintah, melakukan demonstrasi dan perilaku lain untuk memenuhi kewajiban dan hak politiknya

Perilaku politik dibentuk oleh beberapa aspek salah satunya adalah aspek perilaku politik mendukung, menolak dan apatis. Perilaku politik mendukung dapat diamati langsung dari perilaku masyarakat juga dapat diketahui dari wawancara yang dilakukan. Secara garis besar perempuan Indramayu memiliki keakifan yang cukup tinggi dalam memberikan hak suara dalam PILKADA. Demikian yang disampaikan oleh seorang ibu rumah tangga ketika dimintai tanggapannya terkait penggunaan hak suara saat PILKADA Desember lalu:

Selain keaktifan dalam memberikan hak suara sebagian perempuan Indramayu juga memiliki pertimbangan dalam memilih, meskipun pertimbagan yang diberikan setiap individu berbedabeda. Sedangkan perempuan Indramayu yang tidak memberikan hak suaranya saat PILKADA biasanya disebabkan karena masalah teknis saat PILKADA berlangsung seperti tidak mendapatkan surat undangan untuk memberikan hak suaranya.

Sedangkan dalam hal keaktifan dalam partai politik, ormas atau lembaga swadaya masyarakat umumnya perempuan Indramayu memilki keaktifan yang beragam. Perempuan yang berprofesi sebagai ibu rumah tangga umumnya tidak aktif berorganisasi atau hanya aktif di organisasi PKK ditingkat desa. Hal ini dipengaruhi oleh faktor sumber daya manusia yang terbatas pada perempuan yang berprofesi ibu rumah tangga.

Jika perempuan yang berprofesi sebagai ibu rumah tangga umumnya tidak aktif berorganisasi maka perempuan yang bekerja cenderung aktif berorganisasi meskipun organisasi yang diikuti beragam. Ada yang aktif diorganisasi profesi, sayap partai dan bahkan bisa menjadi ketua LSM di Indramayu. Perempuan yang aktif berorganisasi umumnya memiliki pendidikan yang tinggi daripada yang tidak berorganisasi. Pendidikan mempu memberikan pengetahuan dan pemahaman politik terhadap individu. Sehingga pendidikan mampu menghantarkan 
perempuan untuk melakukan orientasi evaluatif terhadap sistem politiknya.

Selain perilaku mendukung aspek perilaku politik lainnya adalah perilaku apatis. Perilaku sebagai perilaku ketidakpedulian terhadap permerintah, politik, isu politik dan segala hal terkait politik. Perempuan Indramayu yang melakukan perilaku apatis umumnya adalah mereka yang berpendidikan rendah. Perempuan yang berpendidikan rendah tidak mengetahui isu yang ada di Indramayu.

Sementara itu perilaku politik menolak dapat diamati dari banyaknya tuntutan yang diberikan oleh masyarakat serta aksi nyata seperti demonstrasi. Perempuan Indramayu yang mampu melakukan perilaku menolak dengan demonstrasi atau membuat tulisan umumnya mereka memiliki pendidikan serta tinggi aktif dalam lembaga swadaya masyarakat. Perilaku menolak ini merupakan bentuk dari orientasi evaluatif yang dilakukan oleh perempuan Indramayu. Seperti perempuan yang aktif dalam Koalisi Perempuan Indonesia (KPI) yang melakukan aksi demonstrasi sebagai bentuk penolakan atas rencana pemerintah menaikan iuran BPJS.

\section{PEMBAHASAN}

Terpilih kembalinya seorang perempuan sebagai Bupati Indramayu berdasarkan hasil PILKADA Desember lalu serta keterwakilan perempuan yang mencapai $22 \%$ di DPRD Indramayu tentu tidak terlepas faktor harapan, kepercayaan, pengetahuan, keyakinan, pertimbangan yang dimiliki oleh masyarakat Indramayu terhadap perempuan. Jika merujuk pada pendapat Gabriel Almond maka harapan, kepercayaan, pengetahuan, keyakinan, pertimbangan yang kemudian di wujudkan dalam perilaku yang dilakukan oleh masyarakat Indramayu merupakan dimensi pembentuk budaya politiknya yaitu orientasi politik dan perilaku politik. Berdasarkan penelitian yang telah dilakukan dapat dipaparkan orientasi politik dan perilaku politik perempuan Indramayu sebagai berikut:

\section{a. Orientasi Politik Perempuan}

\section{Indramayu}


Perempuan indramayu sudah mampu mengetahui dan menyadari hak nya sebagai warga negara dengan memberikan suara saat PILKADA berlangsung. Hal ini dapat dilihat dari tingginya partisipadi pada PILKADA Desember lalu. Sedangkan perempuan Indramayu yang tidak memberikan hak suaranya saat PILKADA biasanya disebabkan karena masalah teknis saat PILKADA berlangsung seperti tidak mendapatkan surat undangan untuk memberikan hak suaranya. Selain keaktifan dalam memberikan hak suara sebagian perempuan Indramayu juga memiliki pertimbangan dalam memilih, meskipun pertimbagan yang diberikan setiap individu berbedabeda.

Ketidakmampuan perempuan Indramayu dalam memberikan pertimbangan atas pilihannya memberikan kemungkinan untuk dimobilsasi melalui money politik dan arahan orang lain. Jika merujuk pada teori budaya politik Gabriel Almond maka kemampuan untuk memberikan pertimbangan sebelum melakukan suatu tindakan berada dalam ranah orientasi evaluatif. Sedangkan ketidakmampuan perempuan Indramayu dalam memberikan pertimbangan dalam memilih dipengaruhi oleh tingkat pendidikan yang masih rendah. Menurut data dari BPS tingkat pendidikan masyarakat Indramayu adalah tamatan sekolah dasar hingga tidak mengherankan mereka memiliki pengetahuan politik yang masih rendah. Maka dapat disimpulkan bahwa perilaku memilih perempuan Indramayu dipengaruhi oleh faktor lingkungan sosial politik langsungnya yaitu tingkat pendidikan.

Mengenai pengetahuan terhadap isu yang ada di Indramayu hanya perempuan yang memiliki tingkat pendidikan yang tinggi atau aktif berorganisasi yang mampu memaparkan isu-isu yang terjadi di Indramayu serta mampu memberikan pendapat rasionalnya terhadap isu tersebut. Berbagai isu yang disampaikan adalah terjadinya money politik pada saat PILKADA, praktek KKN di dunia pendidikan serta adanya upaya untuk membuat masyarakat bungkam ketika adanaya isu dengan memberikan sumbangan. Jika merujuk teori budaya politik yang disampaikan oleh Gabriel Almond kemampuan dalam 
mengetahui hak dalam memilih serta isu yang ada di Indramayu saat ini merupakan ranah dari orientasi kognitif.

Meskipun adanya banyak isu yang dirasakan oleh perempuan Indramayu namun belum banyak perempuan Indramayu yang mewujudkan apa yang dirasakan dan membuat penilaian untuk kemudian diwujudkan dalam bentuk perilaku menolak. Hanya perempuan Indramayu yang memiliki tingkat pendidikan yang tinggi dan aktif berorganisasi yang mampu mewujudkan orientasi evaluatifnya melalui perilaku menolak seperti demonstrasi. Jika merujuk pada teori budaya politik yang disampaikan oleh Gabriel Almond maka perempuan Indramayu belum dapat melakukan orientasi evaluaifnya dengan baik hal ini dipengaruhi oleh orientasi kognitif yang masih rendah.

Fakta yang menunjukkan banyaknya perempuan Indramayu yang terjun ke ranah politik hal ini tidak dapat dipisahkan dari sikap dan karakter perempuan Indramayu yang dapat mewujudkan hal tersebut. karakteristik sosial masyarakat masyarakat pesisir umumnya adalah terbuka, egaliter, keras dan tegas. Perempuan pesisir mereka memiliki tangguh hal ini dilihat dari kemampuan mereka mestabilkan ekonomi keluarga dengan membantu suami yang pengahasilannya tidak menentu dengan mengolah hasil tangkapan lalu menjualnya. Keadaan yang semacam ini membuat perempuan Indramayu merasa mampu untuk terjun ke ranah politik sejajar dengan laki-laki. Karakter masyarakat yang terbuka memungkinkan masyarakat menerima kebijakan afirmasi untuk menyertakan $30 \%$ perempuan dalam politik sebagai wujud dari kesetaraan gender. Maka dapat simpulkan bahwa budaya politik di Indramayu dipengaruhi oleh letak geografisnya yaitu pesisir.

Penerimaan perempuan Indramayu terhadap kebijakan afirmasi ini membuat perempuan Indramayu memiliki harapan terhadap perempuan yang terjun ke ranah politik saat ini. Banyaknya perempuan yang terjun ke ranah politik ini diharapkan mampu mengurangi citra negatif perempuan Indramayu, menghasilkan suatu kebijakan yang melindungi hak-hak 
perempuan, menjadi role model, lebih peduli kepada rakyat dan menggunakan sifat keibuan dalam berpolitik. Jika merujuk pada teori orientasi afektif yang dikemukakan Gabriel Almond maka orientasi afektif perempuan Indramayu sudah baik hal ini ditandai dengan perenerimaan perempuan Indramayu terhadap aktor politik perempuan dan besarnya harapan perempuan Indramayu terhadap aktor tersebut. Jadi dapat disimpulkan bahwa orientasi politik perempuan Indramayu lebih bersifat afektif normatif daripada kognitif.

\section{b. Perilaku Politik Perempuan Indramayu}

Sebagai manifestsi dari orientasi politiknya perilaku politik dibagi menjadi tiga yaitu perilaku mendukung, apatis dan menolak. Dalam keaktifan perempuan Indramayu dalam organisasi politik masih kurang baik. Perempuan Indramayu yang berprofesi sebagai ibu rumah tangga biasanya tidak aktif dalam organisasi. Kalaupun mereka aktif dalam berorganisasi biasanya hanya aktif di organisasi PKK tingkat desa. Berbeda dengan perempuan yang berprofesi sebagai ibu rumah tangga, perempuan Indramayu yang memiliki tingkat pendidikan yang tinggi biasanya aktif berorganisasi. Seperti aktif dalam organisasi keprofesian, sayap partai dan lembaga swadaya masyarakat.

Kemampuan perempuan Indramayu dalam mengkritisi pemerintah atau demonstrasi sebagai bentuk perilaku menolaknya masih kurang baik. Hanya perempuan yang dengan tingkat pendidikan yang tinggi dan aktif di lembaga swadaya masyarakat yang mampu melakukan hal tersebut. Perilaku menolak ini merupakan bentuk dari orientasi evaluatif yang dilakukan oleh perempuan Indramayu. Seperti perempuan yang aktif dalam Koalisi Perempuan Indonesia (KPI) yang melakukan aksi demonstrasi sebagai bentuk penolakan atas rencana pemerintah menaikan iuran BPJS. Sedangkan perempuan Indramayu yang tidak aktif di LSM cenderung memilih apatis atau memilih untuk tidak memilih kembali pejabat yang korupsi sebagai bentuk orientasi politiknya.

Berdasarkan keaktifan dalam mengikuti oragnisasi dan keaktifan 
dalam mengktitisi pemerintah dapat disimpulkan bahwa perilaku politik perempuan Indramayu cenderung apatis terhadap politik. Keapatisan tersebut dipengaruhi oleh ketidakmampuan perempuan Indramayu dalam mewujudkan penilaian yang dimiliki kedalam perilaku menolak sebagai input sistem politik. Ketidakmampuan melakukan perilaku menolak tersebut dipengaruhi oleh tingkat pendidikan dan keaktifan perempuan Indramayu dalam organisasi. Maka perilaku apatis perempuan Indramayu dipengaruhi oleh faktor lingkungan sosial politik langsungnya yaitu tingkat pendidikan.

Selain belum mampu meningkatkan kesejahteraan, kemandirian dan kemajuan pada masyarakat di Indramayu pemerintah juga belum mampu menghasilkan kebijakan yang efektif untuk memperbaiki citra negatif perempuan Indramayu. Kebijakan yang dibuat hanya menyelesaikan apa yang tampak namun belum didapat menyelesaikan masalah dari akarnya. Bukan hanya dinilai belum mampu memperbaiki citra negatif yang ada di Indramayu banyaknya perempuan
Indramayu yang terjun ke ranah politik juga belum berdampak pada terlindunginya hak-hak perempuan di Indramayu. Seperti yang diketahui bahwa perempuan Indramayu banyak yang menjadi buruh migran ke Timur Tengah. Perempuan yang menjadi pahlawan devisa negara ini sangat riskan terhadap tindakan-tindakan kekerasan yang dilakukan oleh majikannya.

Selain tidak mampu menghasilkan kebijakan yang berkualitas serta kurang maksimal dalam mengimplementasikan kebijakan indikator penting belum berkualitasnya aktor politik perempuan yang saat ini memimpin Indramayu saat ini dapat dilihat dari ketidaktahuan anggota DPRD terhadap peran dan fungsinya. Salah seorang anggota DPRD perempuan di Indramayu tidak dapat membedakan antara program dari badan legislatif dengan program dari badan eksekutif. Beliau mengatakan PKK adalah program dari DPRD untuk melindungi hak-hak perempuan di Indramayu. Padahal PKK merupakan salah satu organisasi yang tidak ada kaitannya dengan DPRD. 
Kurang berkualitasnya sosok aktor politik perempuan yang saat ini memimpin Indramayu baik di bidang eksekutif maupun bidang yudikatif juga dapat dilihat dari ketidakmampuan aktor politik perempuan ini dalam membangun opini publik. Keterampilan seorang aktor politik dalam membangun opini publik dinalai sangat penting. Karena dapat meningkatkan legitimasi saat seorang aktor mengambil kebijakan. Namun sayangnya tidak satupun dari perempuan yang saat ini memimpin Indramayu yang melakukan pembangunan opini publik dengan menulis opini di surat kabar ataupun buku.

Setelah ditelusuri track record dari perempuan yang terjun ke ranah politik saat ini rata-rata mereka hanya aktif di PKK dan bahkan ada yang tidak aktif berorganisasi. Meski tidak aktif dalam berorganisasi namun mereka adalah isteri dari mantan bupati, camat, atau kuwu. Keaktifan mereka dalam PKK juga rata-rata karena mereka adalah istri dari pejabat di daerah. Sedangkan setelah ditelusuri tingkat pendidikannya bupati Indramayu saat ini hanya menyelesaikan pendidikan formal sampai SMA melalui persamaan. Namun pada PILKADA Desember lalu ijazah bupati ini diragukan keasliannya hingga digugat oleh rival politiknya yaitu pasangan Toto Sucartono dan Rasta Wiguna ke Mahkamah Konstitusi. Diduga KPU melakukan kesalahan dengan tidak memverifikasi keaslian ijazah dari Anna Sophanah selaku calon bupati Indramayu. Bukan hanya bupati anggota DPRD perempuan saat ini rata-rata mereka hanya lulusan SMA/D3. Dari sebelas orang anggota DPRD perempuan hanya orang orang yang saat ini telah menyelesaikan pendidikannya sampai D3 sedangkan sembilan lainnya hanya sampai sekolah menengah atas (SMA).

Jadi dapat disimpulkan bahwa perilaku politik perempuan Indramayu yang terjun ke ranah politik saat ini dipengaruhi oleh faktor lingkungan sosial politik tak langsung yaitu budaya patriarki dan parton-client serta faktor lingkungan sosial politik langsung yang mempengaruhi dan membentuk kepribadian aktor pendidikan. Sedangkan faktor yang mempengaruhi budaya politik perempuan Indramayu adalah 
karakteristik sosial masyarakat pesisir, tingkat pendidikan, dan budaya patriarki.

Sedangkan jika kita merujuk pada teori yang disampaikan oleh Gabriel Almond perempuan Indramayu memiliki budaya politik subjek (kaula). Hal ini karena terpenuhinya beberapa indikator yaitu tingginya patisipasi politik, memiliki harapan kepada sistem politik (afektif), ketidakmampuan melakukan orientasi evaluatif, rendahnya frekuensi perilaku menolak, pengetahuan politik yang belum mumpuni (kognitif), serta orientasi lebih bersifat afektif dan normatif daripada kogitif. Faktor yang mempengaruhi budaya politik perempuan Indramayu adalah letak geografis, tingkat pendidikan dan budaya patriarki .

\section{KESIMPULAN}

Orientasi politik perempuan Indramayu lebih bersifat afektif normatif daripada kognitif. Hal ini ditandai dengan perenerimaan perempuan Indramayu terhadap aktor politik perempuan, besarnya harapan perempuan Indramayu terhadap aktor tersebut, rendahnya pengetahuan politik dan ketidakmampuan perempuan Indramayu dalam melakukan orientasi evaluatifnya. Hal ini dipengaruhi oleh tingkat perndidikan perempuan Indramayu. Perempuan Indramayu aktif dalam melakukan perilaku memilihnya. Namun dalam melakukan perilaku menolak perempuan Indramayu belum banyak yang dapat melakukan hal tersebut. Perilaku menolak sebagai orientasi evaluatif hanya dapat ditunjukan oleh perempuan Indramayu yang aktif dalam organisasi politik dan berpendidikan tinggi. Sedangkankan sebagian besar perempuan Indramayu menunjukkan perilaku yang mendukung saja. Hal ini biasanya ditunjukkan oleh perempuan Indramayu yang berpendidikan rendah. Maka perilaku politik perempuan Indramayu tersebut banyak dipengaruhi oleh faktor lingkungan sosial politik langsungnya yaitu tingkat pendidikan.

Sementara itu perempuan Indramayu yang terjun ke ranah politik saat ini menunjukkan ketidakmampuan melakukan perilaku politik (membuat, mengevaluasi dan menimplementasikan kebijakan). Hal 
ini dipengaruhi oleh faktor lingkungan sosial politik tak langsung yaitu budaya patriarki faktor lingkungan sosial politik langsung yang mempengaruhi dan membentuk kepribadian aktor pendidikan.

$$
\text { Perempuan Indramayu }
$$

memiliki budaya politik subjek (kaula). Hal ini karena terpenuhinya beberapa indikator yaitu tingginya patisipasi politik, memiliki harapan kepada sistem politik (afektif), ketidakmampuan melakukan orientasi evaluatif, rendahnya frekuensi perilaku menolak, pengetahuan politik yang belum mumpuni (kognitif), serta orientasi lebih bersifat afektif dan normatif daripada kogitif. Sedangkan faktor yang mempengaruhi budaya politik perempuan Indramayu adalah letak geografis, tingkat pendidikan dan budaya patriarki.

\section{DAFTAR PUSTAKA}

Abdullah, Ubed. 2002. Politik Identitas Etnis Pergulatan Tanda Tanpa Identitas. Magelang: Indonesiatera.

Anggara, Sahya. 2013. Sistem Politik Indonesia. Bandung: Pustaka Setia.
Budiardjo, Miriam. 2008. DasarDasar Ilmu Politik. Jakarta: PT Gramedia Putaka Utama

Cresswell, John W. 2013. Research Design Pendekatan Kualitatif, Kuantitatif dan Mixed. Yogyakarta: Pustaka Pelajar. Yogyakarta.

Damsar. 2010. Pengantar Sosiologi Politik. Jakarta: Kharisma Putra Utama.

Daulay, Harmona. 2007. Perempuan dalam Kemelut Gerder. Medan: USU Press.

Duverger, Maurice. 2010. Sosiologi Politik. Jakarta: PT RajaGrafindo Persada.

Faulks, Keith. 2010. Sosiologi Politik Pengantar Kritis. Bandung: Nusa Media.

Koentjaraningrat. 1990. Pengantar Ilmu Antropologi. Jakarta: PT Rineka Cipta.

Mas'oed, $\quad$ Mohtar. 1995. Perbandingan Sistem Politik. Yogyakarta: Gadjah Mada University Press.

Puspitawati, Herien. 2012. Gender dan Keluarga (Konsep dan Realita Indonesia). Bogor: PT Penerbit IPB Press.

Raga Maran, Rafael. 2007. Pengantar Sosiologi Politik. Jakarta: PT Rineka Cipta

Ranjabar, Jacobus. 2006. Sistem Sosial Budaya Indonesia. Ghalia Indonesia. Bogor. 
Sastroatmodjo, Sudijono. 1995. Perilaku Politik. Semarang: IKIP Semarang Press.

Satria, Arif. 2002. Pengantar Sosiologi Masyarakat Pesisir. Jakarta: PT Pustaka Cidesindo.

Setiadi, Elly M. Dan Usman Kolip. 2013. Pengantar Sosiologi Politik. Jakarta: Kencana Prenadamedia Group.

Sjamsuddin, Nazarudin. 1993. Dinamika Ssitem Politik Indonesia. Jakarta: Gramedia Pustaka Utama.

Surbakti, Ramlan. 2010. Memahami Ilmu Politik. Jakarta: Grasindo Anggota IKAPI.

Sugiyono. 2008. Metodologi Penelitian Pendidikan Pendekatan Kuantitatif, Kualitatif dan $R \& D$. Bandung: Alfabeta.

Soetjipto, Ani dkk. 2013. Gender dan Hubungan Internasional. Yogyakarta: Jala Sutra Anggota IKAPI.

Upe, Ambo. 2008. Sosiologi Politik Kontemporer. Jakarta: Prestasi Pustaka Publiser.

Widjaja, Albert. 1988. Budaya Politik dan Pembangunan Ekonomi. Jakarta: LP3S.

Zuhro, R. Siti, dkk. 2009. Demokrasi Lokal Perubahan dan Kesinambungan Nilai-nilai Budaya Politik Lokal di Jawa Timur, Sumatera Barat,
Sulawesi Selatan dan Bali. Yogyakarta: Ombak.

Zuhro, R. Siti, dkk. 2009. Peran Aktor Dalam Demokratisasi. Yogyakarta: Ombak Indeks Pembangunan Gender Kabupaten Serang. 2013. BAPPEDA Kabupaten Serang. Serang

\section{Sumber Jurnal:}

Jalaluddin, Rahmat. (1994). "Dari Psikologi Androsentris ke Psikologi Feminis (membongkar mitos-mitos tentang perempuan)". Ulumul Qur'an. Vol. 5. No. 5 \& 6. Hlm 22

Partini. (2014). Partisipasi Politik Perempuan dalam Praktik Kewarganegaraan di Indonesia. Jurnal Perempuan. Vol 19. No. 2. Hlm 41

Partini. (2014). Partisipasi Politik Perempuan dalam Praktik Kewarganegaraan di Indonesia. Jurnal Perempuan. Vol 19. No. 2. Hal 29

Rinantasari, Dian. (2013). "Di Tengah Pragamatisme Politik: Pola Orientasi Politik Pemula Pelajar SMU se DKI Jakarta". Sosialita. Vol 8. No 3 \& 4 . Hlm 18

Wiji Rahayu, Angger. (2012) Perempuan Pejabat Publik. Mitos, Data dan Fakta Perempuan Pemimpin. Jurnal Perempuan. Vol. 17. No 4. Hlm 68 
Wiji Rahayu, Angger. (2012) Perempuan Pejabat Publik. Mitos, Data dan Fakta Perempuan Pemimpin. Jurnal Perempuan. Vol. 17. No 4. Hlm 69

\section{Sumber Internet:}

Radarcirebon.com/gedung-dewanpenuh-wajah-baru.html. diunduh 22 November 2015 pukul 23.08 